\title{
Społeczna wiedza i legitymizacja a przemiany polskiego uniwersytetu
}

\begin{abstract}
STRESZCZENIE. W ciągu ostatniej dekady polski system szkolnictwa wyższego i nauki został poddany serii reform radykalnie zmieniających jego stosunki z państwem. Jednocześnie znaczącej transformacji uległ jego wizerunek w strefie publicznej. W przebiegu debaty nad pożądanym kierunkiem reform akademia - jej pracownicy, praktyki i formy instytucjonalne - zostały poddane silnej krytyce. Celem tego artykułu jest opis mechanizmów zmian, jakie dokonały się w zakresie publicznej wiedzy i legitymizacji systemu szkolnictwa wyższego i nauki w potransformacyjnej Polsce. Analiza opiera się na badaniu materiałów prasowych pochodzących z Gazety Wyborczej i jej wydań lokalnych z lat 1989-2014. Efekty debaty publicznej obejmującej lata 2008-2014 są interpretowane jako kryzys legitymizacji polskiego uniwersytetu, wymuszający przejście z tradycyjnego dla akademii trybu legitymizacji opartego na społecznym autorytecie do racjonalnych form legitymizacji opartych na precyzyjnej definicji produktów i silnie zapośredniczonej przez aparat państwowy.
\end{abstract}

SŁOWA KLUCZOWE: wykształcenie wyższe, legitymizacja, analiza dyskursu, kryzys legitymizacji

\section{Wprowadzenie}

Historia polskiej akademii po 1989 r. jest historią gwałtownego wzrostu - od edukacji elitarnej i darzonej dużym szacunkiem społecznym do umasowionej, posiadającej mniejszy prestiż, ale i stanowiącej niezbędny element nawet najskromniejszej z mieszczańskich karier - i równie gwałtownego upadku, wywołanego jednym z najgłębszych w Europie niżów demograficznych (Antonowicz, Godlewski 2011; Kwiek 2013). Jest też historią wycofania się i powrotu państwa do roli regulatora i zarządcy sektora (Kwiek 2016a; 2016b). Zmianom tym towarzyszyło całkowite przewartościowanie obrazu akademii w sferze publicznej. Autorytet szkół wyższych długo osłaniał je przed krytyką, którą pod wpływem rynkowego fundamentalizmu 
pierwszych potransformacyjnych dekad kierowano wobec większości publicznych instytucji. Sytuacja ta zmieniła się nagle i radykalnie podczas rozpoczętej w $2008 \mathrm{r}$. debaty nad reformami sektora. Wytworzony w tym czasie dyskurs o szkolnictwie wyższym towarzyszy nam do dziś.

Celem artykułu jest przedstawienie, na podstawie wyników badania materiałów prasowych oraz pojęć zaczerpniętych z instytucjonalnej teorii organizacji ${ }^{1}$, mechanizmów odpowiedzialnych za zmiany, jakie dokonały się w zakresie publicznej wiedzy i legitymizacji systemu szkolnictwa wyższego i nauki (SWiN) w Polsce. Zawiera on też próbę powiązania kwestii legitymizacji i wiedzy z czynnikami, które równolegle kształtowały akademię: demografią, relacjami pomiędzy aktorami sektora i rolą odgrywaną w systemie przez państwo.

Przedmiotem badania materiałów prasowych był dyskurs dotyczący „uniwersytetu”, który według autorów analizowanych publikacji obejmuje zarówno instytucje posiadające prawo do tej nazwy, jak i prowincjonalne szkoły wyższe. Moim celem nie jest jednak przedstawienie „historii idei” akademii we współczesnej Polsce, ale prześledzenie kulturowych i dyskursywnych czynników, w takim zakresie, w jakim były one powiązane z materialnym bytem szkół wyższych jako organizacji.

Artykuł składa się z trzech części, przedstawiających kolejno: wykorzystywaną jako baza do badania teorię legitymizacji i dyskursu, wyniki badań empirycznych materiałów prasowych oraz próbę rekonstrukcji roli państwa i rynku w kryzysie legitymizacji polskiej akademii.

\section{Organizacje, legitymizacja i dyskurs}

Uniwersytety zajmują specyficzne miejsce wśród możliwych form organizacyjnych. Bogata historia akademii świata zachodniego, a także ich tradycyjne powiązanie ze społecznymi elitami i wkład członków akademickiej wspólnoty w cywilizacyjny rozwój, jakiego doświadczamy od XVIII wieku, dawały im tradycyjnie kredyt społecznego zaufania porównywalny z tym, jakim w krajach Zachodu cieszyły się wyłącznie kościoły i aparaty państwowe. Akademia należała do sfery zinstytucjonalizowanego sacrum, była „napełniona wartością wykraczającą poza techniczne wymagania danego przedsięwzięcia” (Selznick 1957: 17). Rozważaną w kategoriach „misji” działalność uniwersytetu uznawano za cel, a nie środek. Zdobywanie wiedzy i poszerzanie dostępu do niej (połączone ze szkoleniem przyszłych jej wytwórców) miały być uzasadnione, w ramach sięgającej Platona tradycji, same przez się.

${ }^{1}$ Ta sama teoria (choć w nieco innej perspektywie, skoncentrowanej na kwestiach międzysektorowej i międzynarodowej dyfuzji wzorców organizacyjnych raczej niż społecznej legitymizacji) stanowi podstawę analiz i badań Dominika Antonowicza (2015a; 2015b). 
Społeczny autorytet uniwersytetów pozwolił im na uniknięcie racjonalizacji, która między XIX a XXI wiekiem dotknęła inne dziedziny życia społecznego, podporządkowując je normom i regułom lub rachunkowi ekonomicznemu i czyniąc ich cele drugorzędnymi wobec imperatywu uzyskania zgodności z kulturowo ugruntowanymi zasadami działania lub wplecenia ich w machinę gospodarki towarowo-pieniężnej. Ta specyficzna sytuacja - funkcjonowania akademii na obrzeżach biurokracji i rynków, za pomocą których współczesne społeczeństwa racjonalizują własną działalność - nie oznacza, że w swej naturze różni się ona od innych organizacji. By działać, uniwersytety potrzebują zasobów materialnych i ludzkich oraz sprzyjającego prawa. Zasoby te nie byłyby im udzielane, gdyby nie posiadały legitymizacji, tzn. gdyby ich społeczne otoczenie nie podzielało „poglądu czy założenia, że [ich] działania są pożądane czy stosowne w ramach jakiegoś [...] systemu norm, przekonań, wierzeń i definicji” (Suchman 1995: 574). Autorytet (nazywany w literaturze legitymizacją kognitywno-kulturową) jest formą legitymizacji przysługującą statecznym instytucjom, zakorzenionym w społecznej świadomości (taken-for-granted) tak silnie, że zasadność ich istnienia i sposób funkcjonowania nie są zazwyczaj podawane w wątpliwość, a alternatywy wobec nich albo nie są traktowane poważnie, albo w ogóle są trudne do wyobrażenia (DiMaggio 1997; Scott 2008).

Organizacje zracjonalizowane opierają się z kolei na legitymizacji normatywno-prawnej, wymagającej stałego dopasowywania się do norm i reguł określających, jakie działania, metody produkcji czy sposoby zarządzania są w danym kontekście społecznym powszechnie uznawane za poprawne, racjonalne i efektywne (Meyer i Rowan 1977), albo na legitymizacji pragmatyczno-rynkowej, opierającej się na efektywności procesów produkcyjnych, których wytwory są sprzedawane na wolnym rynku.

Specyficzną cechą organizacji opierających się głównie na kognitywno-kulturowych czy regulacyjno-prawnych źródłach legitymizacji jest to, że ich produkty czy usługi z trudnością poddają się kwantyfikacji, wycenie czy nawet opisowi. Instytucje kultury, kościoły, uniwersytety, rozmaite organizacje posiadające „strategiczne znaczenie dla państwa”, a nawet wytwarzające „zdrowie” szpitale i przychodnie roszczą sobie prawo do istnienia na podstawie nieprecyzyjnie zdefiniowanego i stale zmieniającego się katalogu usług, zawierającego często pozycje, których istnienia czy społecznego wpływu nie sposób zweryfikować (Meyer i Rowan 1977). Wobec niejasności dotyczącej tego, co dokładnie wytwarzają (czy niemożliwości lub niechęci danego społeczeństwa do wyceniania ich produktów za pomocą rynku) ich istnienie musi opierać się na autorytecie lub społecznej kontroli procedur produkcyjnych. Oznacza to, że mogą one doświadczać długich okresów, w których uznana społecznie oczywistość (lub poprawność) ich działań będzie je chronić przed zewnętrzną ingerencją i kontrolą czy opartą na rachunku ekonomicznym oceną ich przydatności (Scott i Meyer 1991). Ochrona przed wyceną produktów i pełną ra- 
cjonalizacją nie jest jednak trwała, organizacje mogą poruszać się pomiędzy rozmaitymi trybami legitymizacji, ponieważ przynależność do nich „nie wynika z [...] technicznych uwarunkowań produkcji [...]. Po pierwsze dlatego, że techniczna ocena wydajności jest społecznie zdefiniowana i nie istnieje w jakimś konkretnym sensie, który podlega obiektywnej ocenie empirycznej. Po drugie dlatego, że środowiska i organizacje często redefiniują naturę produktów, usług i technologii. Taka redefinicja może albo wyklarować, na czym polegają techniki produkcji i umożliwić ich obiektywną ocenę [...], może jednak również uczynić sytuację bardziej niejasną, czyniąc ją oporną na inspekcje i kontrolę" (Meyer i Rowan 1977: 354)².

Wiąże się z tym stałe zagrożenie, będące stawką kontaktów utrzymywanych przez organizacje z ich społecznym otoczeniem, że w wyniku zmiany norm, metod pomiaru czy prawa status danej organizacji może się zmienić. To, do jakiej kategorii jest zaliczana, czy jakie obowiązują ją normy, wynika z przemian dokonujących się na poziomie kultury i dyskursu. Zmiana norm, potwierdzenie dopasowania do nich lub reinterpretacja istniejących praktyk, tak by wydawały się z nimi zgodne, próby rozjaśnienia (lub uczynienia bardziej niejasnym) katalogu produktów i usług dostarczanych przez daną organizację, przejawiają się w pierwszej kolejności w sferze publicznej wiedzy i komunikacji.

Oznacza to, że dyskurs - definiowany tu jako skodyfikowana wiedza, produkowana na potrzeby i komunikowana w sferze publicznej (Stankiewicz 2014) - jest dziedziną, którą przedstawiciele organizacji muszą stale nadzorować, próbując nie dopuścić do pojawienia się wiedzy mogącej zmienić opinię, jaką otoczenie społeczne posiada na ich temat. $\mathrm{Z}$ tego względu organizacje opierające się na społecznej „oczywistości” (taken-for-grantedness) i/lub powszechnie uznanej poprawności i racjonalności swoich działań preferują całkowitą konwencjonalność dotyczącego ich przekazu (Ashforth i Gibbs 1990; Deephouse 1996). Bycie przedmiotem uwagi mediów (czy jakichkolwiek innych sił społecznych), wykraczającej poza przewidywalne, zrytualizowane formuły, grozi zakłóceniem obrazu organizacji, powstaniem wiedzy na temat jej rzeczywistych praktyk (a te są często odmienne od ich konwencjonalnej dyskursywnej reprezentacji) i w konsekwencji wycofaniem poparcia lub żądaniem nasilenia nadzoru. Potrzeba ochrony instytucjonalnej tożsamości przed zewnętrzną ingerencją powoduje też, że choć organizacje stale komunikują się ze swoimi publicznościami, to jednocześnie nie posiadają motywacji do wytwarzania i rozpowszechniania rzetelnej i aktualnej wiedzy na swój temat.

Gdy organizacja traci społeczne poparcie, można mówić, że znalazła się w kryzysie legitymizacji. Kryzysy legitymizacji obejmują zarówno sytuacje, z których dana organizacja czy sektor może wydobyć się za pomocą mechanizmów zarządzania

\footnotetext{
${ }^{2}$ Publikacją, zawierającą bardzo wnikliwą analizę kwestii mierzalności akademickich „produktów", a także sposobu i przyczyn, dla których ich status podlega współcześnie zmianie, jest Uniwersytet jako dobro wspólne Krystiana Szadkowskiego (2015).
} 
wizerunkiem - używając takich strategii, jak: zaprzeczanie, wymówki, uzasadnienia, wyjaśnienia, strategiczne restrukturyzacje (Suchman 1995), jak i sytuacje poważniejsze - gdy społeczni aktorzy, od których zależy trwanie organizacji, w odpowiedzi na mniej lub bardziej przypadkowe wydarzenia przestają jej ufać do tego stopnia, że konieczna jest szeroka restrukturyzacja jej stosunków ze społecznym otoczeniem. Społeczna debata jest jednym ze sposobów, na jaki aktorzy organizacyjni, ich publiczność i interesariusze ustalają przyczyny zerwania społecznych powiązań i planują ich rekonstrukcję. Ponieważ legitymizacja wiąże się ze sposobami, na jakie społeczeństwo wycenia, zarządza i rozumie działalności prowadzone w jego różnych sektorach, więc jej rozległe kryzysy, niewątpliwie bolesne dla poddanych im organizacji, destabilizują również powiązane z nimi społeczności. Oddala to poważne kryzysy legitymizacji od wzorca „paniki moralnej” (Goode i Ben-Yehuda 1994), często towarzyszącej medialnej diagnozie rozmaitych społecznych bolączek i zbliża do kryzysów o „obiektywnej” naturze - politycznych czy gospodarczych. Kryzys legitymizacji jest w takiej sytuacji stanem rozkładu pojęć i teorii, za pomocą których aktorzy społeczni opanowują i oswajają społeczną rzeczywistość. Rekonstrukcja społecznego kontraktu może, jak w opisanym przez Boba Jessopa (2002) mechanizmie wychodzenia z kryzysów reżimów gospodarczych, wymagać długotrwałej i złożonej negocjacji.

To, które z rozwiązań zostanie przyjęte, jest częściowo wynikiem dyskursywnych sporów co do natury, znaczenia i konsekwencji kryzysu. W okresach szerokiej społecznej restrukturyzacji dochodzi do konfrontacji zróżnicowanych ekonomicznych, politycznych i społeczno-kulturowych narracji, których celem jest wyjaśnienie sensu zaistniałych problemów przez ich interpretację w kontekście minionych porażek i nadchodzących szans (Jessop 2002: 92).

Kluczową rolę odgrywa rywalizacja indywidualnych i kolektywnych sił [...] artykułujących strategie, projekty i wizje mające załagodzić sprzeczności i konflikty. [...] Głównymi siłami zaangażowanymi w tę rywalizację są grupy interesu, partie polityczne i ruchy społeczne, przy czym to media masowe [...] posiadają główną pozycję pozwalającą na zapośredniczenie sporu dotyczącego hegemonii (Jessop 2002: 22).

Reagujący na kryzys aktorzy społeczni muszą wyjaśnić przyczyny porażki, co wymaga reinterpretacji minionych wydarzeń i przewartościowania wielu sądów dotyczących rzeczywistości oraz - na podstawie tych ustaleń - zaproponować nieopierającą się na wcześniejszych błędach drogę wyjścia z sytuacji.

Ponieważ w przebiegu społecznej restrukturyzacji zagrożone są interesy wielu aktorów, towarzyszące kryzysom debaty niekoniecznie muszą być zgodne z wzorcem racjonalnej deliberacji. Ich przebieg będzie raczej zbliżony do dyskursywnego starcia, w którym wiedza, kapitał polityczny, poziom zorganizowania i dostęp do kanałów komunikacji będą instrumentalnie wykorzystywane do zabezpieczenia przyszłych interesów dysponujących nimi grup. 
Kolejna część poświęcona jest opartej na danych empirycznych historii sporu, którego stawką była społeczna legitymizacja i - w ostatecznym rozliczeniu - instytucjonalna tożsamość polskiego uniwersytetu.

\section{Kryzys legitymizacji}

Do 1989 r. polskie szkoły wyższe były instytucjami elitarnymi, całkowicie zdominowanymi przez państwo, przeznaczające zarówno na badania naukowe, jak i na dydaktykę znaczne, w stosunku do wielkości gospodarki, sumy. Tak jak w innych społeczeństwach Europy Środkowo-Wschodniej, w których nie doszło do uformowania klasycznie rozumianej burżuazji, klasa wykształcona i instytucje, w których zdobywała ona wykształcenie, obdarzano dużym szacunkiem społecznym (Stankiewicz 2016).

Ze wszystkich wymienionych powyżej cech - elitarności, wysokiego finansowania, publicznego charakteru i społecznego szacunku - tylko ostatnia przetrwała pierwsze potransformacyjne lata. Całkowita przemiana szkół wyższych po $1989 \mathrm{r}$. wynikała z oddziaływania trzech czynników. Pierwszym z nich była liberalizacja, której przejawami było odzyskanie przez uniwersytety tradycyjnych wolności (Antonowicz 2015a), uzyskanie możliwości sprzedaży usług edukacyjnych, tworzenia szkół niepublicznych, a także długotrwała regulacyjna bierność państwa, „polityka braku polityki” (Kwiek 2009), wraz z uwolnieniem sił rynkowych stanowiąca podstawę polskiego akademickiego leseferyzmu. Drugim - polityka oszczędności, w wyniku której nakłady na działalność naukową spadły z poziomu o,8\% PKB w 1991 r. do 0,3\% PKB w 2005 r. (Wolszczak-Derlacz i Parteka 2010), a wydatki na edukację na poziomie wyższym w przeliczeniu na studenta, przez większość pierwszej potransformacyjnej dekady oscylujące między 0,7\% i 0,8\% PKB, uległy znacznej redukcji w stosunku do stale rosnącej liczby kształcących się. Te dwa czynniki, stanowiące przejaw wycofywania się państwa ze sfery szkolnictwa wyższego, były jednocześnie warunkami gwałtownego rozwoju sektora. Pierwszy z nich umożliwił komercjalizację i substytucję środków publicznych przez kapitał prywatny, drugi wymusił ją, pauperyzując instytucje i ich pracowników.

Połączenie presji finansowej i wolności ekonomicznej nie wpłynęłoby na uniwersytety, gdyby nie trzeci motor zmian - wynikające z pojawienia się bezrobocia i znacznej premii płacowej dla osób wykształconych zwiększenie popytu na uniwersyteckie dyplomy, z czasem generujące nieformalny przymus edukacyjny dotyczący edukacji trzeciego stopnia (Stankiewicz 2015).

Zmiany te umożliwiły dynamiczny rozwój systemu szkolnictwa wyższego. Pomiędzy 1991 a 2002 r. średni roczny przyrost liczby studentów wynosił 13,5\%. W okresie najintensywniejszego wzrostu (1992-2000) sektor powiększał się każdego roku o ponad $15 \%$. 
Pomimo znaczącej restrukturyzacji autorytet uniwersytetu przez długi czas nie został nadszarpnięty. Wiedza na temat zachodzących w nim zmian, w tym negatywnych konsekwencji umasowienia, przenikała do społecznej świadomości (i mediów masowych) bardzo powoli. Warto zatem prześledzić powiązane ze sobą procesy przystosowywania się dyskursu do nowej rzeczywistości i wpływu tych zmian na autorytet - i w konsekwencji stopień społecznej legitymizacji - uniwersytetów i całego systemu szkolnictwa wyższego i nauki.

Moim narzędziem była analiza publikacji prasowych największego polskiego dziennika opinii - Gazety Wyborczej (i jej wydań lokalnych) z lat 1989-2014³. Media są przestrzenią, w której przejawiają się kulturowe przekonania i normy dotyczące różnych obszarów ludzkiej działalności. Są one też uznawane, zarówno w analizach legitymizacji (Suchman 1995; Asforth i Gibbs 1990; Deephouse 1996), jak i teorii kryzysów Jessopa (2002), za przestrzeń, w której organizacje i sektory organizacji budują, utrzymują i tracą legitymizację. Analiza ich dyskursu pozwala zarówno na zdanie sprawy z procesu ewolucji społecznej świadomości, jak i na bliższą analizę poważnych kryzysów społecznego zaufania - momentów, w których rekonstrukcji podlega większość dotychczasowej wiedzy i w których aktorzy zastanawiają się nad przyszłymi rozwiązaniami lub walczą o ich kształt. Głównym przedmiotem mojego zainteresowania były natężenie i treść krytycznych dyskusji wokół systemu szkolnictwa wyższego, czas pojawiania się nowych tematów dotyczących szkół wyższych i momenty, w których dochodziło do przewartościowań społecznych sądów - gdy na nowo interpretowano zastane już dane. Pominięte zostały publikacje stanowiące przejaw rytualnych procesów legitymizacji i opisy odosobnionych przypadków4

Historię polskiego szkolnictwa wyższego po 1989 r. można podzielić na trzy okresy: gwałtownego wzrostu (1990-2001), stagnacji (2002-2010) i kontrakcji (od $2011 \mathrm{r}$.). W pierwszym z nich, mimo że był to czas najbardziej dramatycznych zmian, liczba krytycznych artykułów dotyczących systemu NiSW była znikoma. Przez cały prawie okres ekspansji, między 1989 a 2000 r., Gazeta Wyborcza opublikowała mniej krytycznych analiz sytuacji szkół wyższych niż w jednym tylko, przypadającym na najgorętszy okres debaty nad reformą minister Barbary Kudryckiej, roku

${ }^{3}$ Dane zostały uzyskane dzięki wyszukiwarce archiwum Gazety Wyborczej (obejmującym również jej wydanie lokalne). W tworzeniu wykresu zostały wykorzystane dane zgromadzone dla potrzeb badania doktorskiego (dla lat 2007-2010), projektu „Urządzanie uniwersytetu”, w którym autor uczestniczy (dla lat 2011-2014), i na potrzeby tego artykułu (dla lat 1989-2006).

${ }^{4}$ Do tych ostatnich zaliczam: artykuły zawierające generalnie sprzyjający opis pojedynczych działań podejmowanych przez dany uniwersytet czy grupę badawczą; zdające sprawę z powtarzalnych, niepodlegających ocenie rytuałów życia akademickiego; podkreślające sukcesy poszczególnych placówek; zawierające publikowane okresowo porady dla przyszłych studentów; rankingi szkół wyższych; sprawozdania ze zmian wprowadzanych w wyniku reform i informacje o reformach publikowane z okazji ich uchwalenia; sprawozdania z kłopotów i niedociągnięć poszczególnych placówek, chyba że osiągnęły one poziom wydań ogólnokrajowych lub były częścią serii opisujących podobne problemy w wielu szkołach w kraju; sprawozdania o sytuacjach mających wyraźny charakter przestępczy. 
2009. Podczas długiego okresu stagnacji (2002-2010) wiedza na temat natury systemu, a także występujących w nim sprzeczności i konfliktów, zaczęła ulegać stopniowej akumulacji. Wreszcie, gdy uczelnie zaczęły odczuwać pierwsze oznaki niżu demograficznego, doszło do, niezakończonej jeszcze, debaty nad szkolnictwem wyższym, w wyniku której dyskurs publiczny dotyczący uniwersytetu uległ całkowitej, i zapewne trwałej, przemianie.

Aż do $2000 \mathrm{r}$. w podlegających analizie artykułach nie wytworzył się żaden spójny obraz systemu NiSW. Jedyną kwestią, z której zdawano sprawę w szerszym zakresie, było niedofinansowanie sektora i związane z nim protesty akademików i studentów. To właśnie sprzeciw wobec cięć budżetowych, w wyniku których pomiędzy 1991 a 1994 r. doszło do 30-proc. spadku dotacji na działalność naukową i dydaktyczną (Wolszczak-Derlacz i Parteka 2010; GUS 2005), był tematem jedynej w tym okresie szerszej dyskusji wokół szkolnictwa wyższego. Miała ona miejsce w latach 1994-1995. Autorami publikowanych w mediach wypowiedzi byli przedstawiciele środowiska akademickiego lub publicyści zdający sprawę z finansowych problemów uczelni, jej pracowników i rosnących rzesz opłacających czesne lub pozbawionych stypendiów studentów. Największy ladunek krytyczny zawarty był w wypowiedziach akademików oskarżających rząd o brak polityki dotyczącej systemu nauki i nauczania i postulujących zmiany w systemie. Ani wypowiedzi z okresu dwuletniego kryzysu, ani całej pierwszej dekady po 1989 r. nie zawierają treści, które można by zinterpretować jako bezpośrednią krytykę uniwersytetu - wskazywane były nieprawidłowości w działania systemu, proponowane pierwsze rozwiązania (wprowadzenie powszechnego czesnego, całkowita prywatyzacja szkół wyższych) i zbierane pierwsze informacje na temat „patologii” płatnego wykształcenia. Zakres tych publikacji był jednak, w porównaniu z pozostałymi okresami, niewielki.

Sytuacja ta uległa zmianie w $2000 \mathrm{r}$. W ciągu kolejnych czterech lat media zaczęły w o wiele bardziej szczegółowy sposób zdawać sprawę z problemów wynikających z komercjalizacji i umasowienia szkolnictwa wyższego - wieloetatowości nauczycieli, niskiej jakości studiów w szkołach niepublicznych, powstawania nielegalnych zamiejscowych punktów edukacyjnych i pobierania nieuprawnionych opłat w szkołach publicznych. Był to pierwszy moment od czasów transformacji, w którym krytyka systemu zaczęła ilościowo dominować nad stałymi (w tym wypadku koncentrującym się w 2001 r.) protestami pracowników uczelni związanymi ze spadającym finansowaniem. Różnica między tym okresem a przypadającą na lata 2008-2014 debatą, polegała na braku systemowego namysłu i braku jasnego przypisania odpowiedzialności za zdiagnozowane problemy. Media relacjonowały odkryte przez siebie „patologie” szkolnictwa wyższego jako pojedyncze przypadki lub szersze tendencje, niemające jednak przełożenia na ocenę całego systemu. Wykorzystywany dyskurs (dotyczy to zresztą całego okresu 1989-2007) był radykalnie odmienny od tego, który ukształtował się w pierwszych latach debaty nad reformą z 2011 r. - nie dochodziło do kwestionowania zasadności umasowienia wykształ- 
cenia wyższego (uznawanego za „cywilizacyjną konieczność”), przypisania uczelniom winy za (wielokrotnie relacjonowany) fakt bezrobocia absolwentów, uznania akademickiej hierarchii za generator patologii czy akademickiej samorządności za czynnik utrudniający przekształcenie systemu. Jakość kształcenia i działalność naukowa szkół publicznych była powszechnie uznawana za porównywalną z uniwersytetami zachodnimi.

Jednocześnie, poczynając od 2000 r., trwa akumulacja wiedzy dotyczącej funkcjonowania umasowionego szkolnictwa wyższego. Wiedza ta została $\mathrm{w}$ okresie późniejszym włączona w narracje obwiniające o stan systemu środowisko pracowników akademickich. Był to też okres, w którym zaczęły pojawiać się propozycje reform (np. wprowadzenia powszechnej odpłatności za studia, likwidacji habilitacji, zmiany modelu kariery naukowej), podjęte później przez koalicyjny rząd Platformy Obywatelskiej i Polskiego Stronnictwa Ludowego.

Wykres 1. Krytyczne artykuły na temat systemu szkolnictwa wyższego i nauki w Polsce w Gazecie Wyborczej i jej wydaniach lokalnych

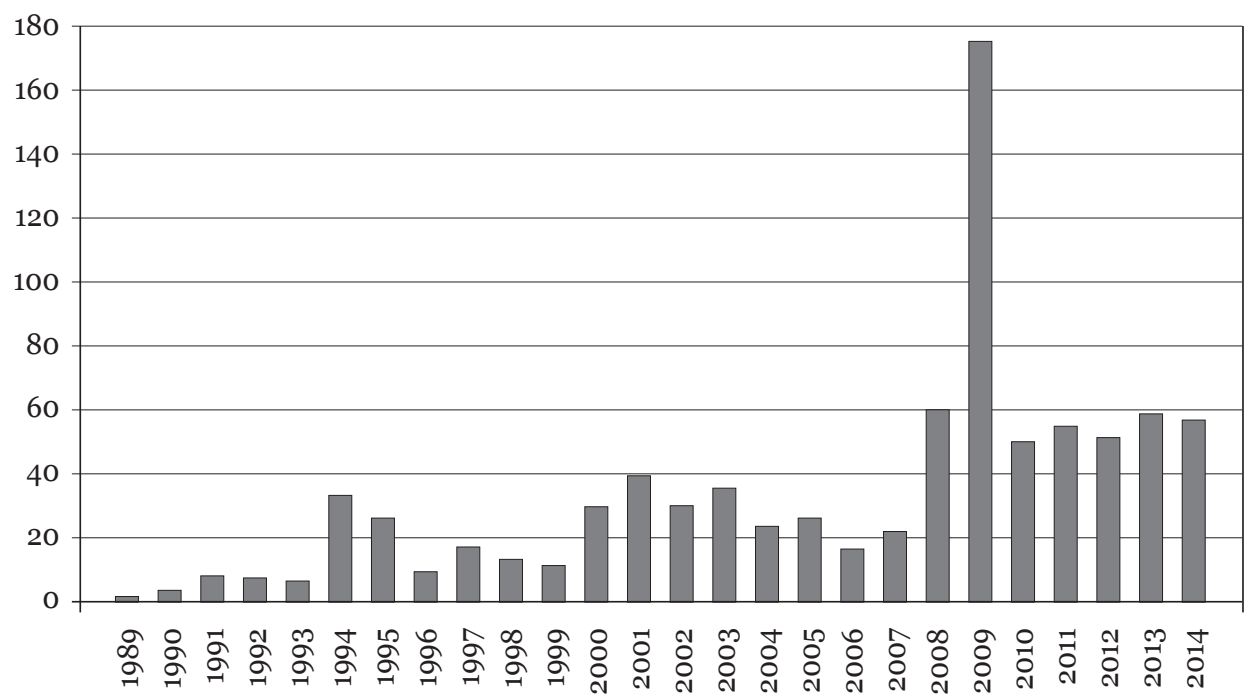

Źródło: opracowanie własne.

Do poważnych zmian we wzorcach interpretacji sytuacji sektora doszło dopiero w 2008 r. Pod koniec 2007 r. urząd ministra nauki i szkolnictwa wyższego objęła prof. Barbara Kudrycka. Zapowiedziała ona prace nad szerokim pakietem reform, mającym zawierać elementy projakościowe (uczelnie flagowe), wyraziła też, zgodną ze stanowiskiem środowiska akademickiego, intencję wprowadzenia powszechnego czesnego. Jeszcze przed rozpoczęciem debaty nad kierunkiem zmian doszło 
do publikacji dwóch dokumentów, które odegrały ważną rolę w jej pierwszej fazie. Pierwszym z nich był, wydany pod koniec 2007 r. i natychmiast przetłumaczony przez Ministerstwo Nauki i Szkolnictwa Wyższego, raport OECD dotyczący edukacji wyższej w Polsce. Drugim - raport z przeprowadzonych w Collegium Civitas badań opinii akademików, opublikowany jako Autodiagnoza polskiego środowiska naukowego. Raport OECD ukształtował opinię aktorów medialnych na temat pożądanego kierunku zmian w systemie edukacji wyższej, natomiast publikacja Collegium Civitas zawierała wiele informacji na temat kondycji środowiska naukowego, w szczególności zjawisk takich jak „feudalizacja” stosunków pomiędzy pracownikami, brak współpracy międzynarodowej czy blokowanie karier młodych pracowników.

W lutym i marcu 2008 r. Gazeta Wyborcza - jeszcze przed ich oficjalnym ogłoszeniem - opublikowała założenia przyszłej reformy sformułowane przez powołany przez ministerstwo zespół ekspercki. Zawierały one punkt dotyczący likwidacji habilitacji, co natychmiast wywołało ostrą reakcję środowiska naukowego - w szczególności humanistów - i rozpoczęło debatę na temat uniwersytetu, która nie została zakończona do dziś.

Pierwsza faza debaty publicznej, pomiędzy ogłoszeniem założeń reformy na początku 2008 r. a jej przegłosowaniem przez parlament trzy lata później, toczyła się wokół treści zmian prawnych i ogólnej strategii rozwoju systemu NiSW. Jednocześnie miał miejsce proces domykania „dyskursywnej luki” pomiędzy społeczną świadomością, ukształtowaną przez obraz elitarnego uniwersytetu z czasów komunistycznych, a nową rzeczywistością zuniwersalizowanej edukacji wyższej.

Już w tych pierwszych latach doszło do sformułowania serii diagnoz dotyczących kondycji systemu NiSW, a dotyczyły one:

- słabości naukowej polskich uniwersytetów, przejawiającej się w niepowodzeniach polskich naukowców w staraniach o granty europejskie, niskiej pozycji lokalnych uniwersytetów w międzynarodowych rankingach, braku współpracy międzynarodowej i braku skłonności pracowników akademickich do publikowania w języku angielskim;

- słabości dydaktycznej, czyli wywołanego umasowieniem drastycznego obniżenia poziomu nauczania w szkołach publicznych i niepublicznych;

- niedopasowania struktury kierunków do rynku pracy. Dominacja „tanich” kierunków, takich jak pedagogika czy zarządzanie, miała nie odpowiadać „potrzebom rynku pracy", a także być irracjonalna z perspektywy przyszłego, opartego na innowacjach technologicznych, rozwoju gospodarki krajowej;

- brak innowacyjności polskiej gospodarki został zinterpretowany jako wynik słabości polskiej nauki czy - później - jako wynik jej niedostatecznej współpracy z przemysłem;

- słabość dydaktyczna, niedopasowanie struktury kierunków do potrzeb pracodawców i nadmiar dyplomów miały znacząco obniżać ich wartość. Stwierdzenie 
tego faktu było równoznaczne ze zdaniem sobie sprawy przez aktorów polskiej strefy publicznej z istnienia zjawiska inflacji dyplomów.

Większość powyższych problemów miała mieć związek z nieracjonalnym (tzn. kolegialnym i demokratycznym zamiast menedżerskiego) systemem zarządzania instytucjami akademickimi, a także nieprawidłowościami, takimi jak nepotyzm czy „feudalizacja” stosunków pomiędzy starszymi i młodszymi pracownikami.

Środowisko akademickie obarczono odpowiedzialnością za inflację dyplomów (nadmierna rekrutacja miała wynikać z chciwości szkół wyższych), niewielką innowacyjność polskiej gospodarki (słaba kondycja nauki miała zniechęcać przedsiębiorców do nawiązywania kontaktów z uniwersytetami), a także za niską jakość kształcenia w szkołach publicznych i niepublicznych. W efekcie, już w przedbiegu reformy, poparcie zyskiwały propozycje bardzo drastycznych ingerencji w autonomię akademicką. O stopniu delegitymizacji systemu może świadczyć fakt, że został on - przez sprzyjających mu wcześniej aktorów medialnych - uznany za sektor społecznej działalności, oczekujący na swoją „terapię szokową”, a pozbawienie istniejącej hierarchii akademickiej wpływu na implementację reform zostało uznane (przez publicystów) za warunek ich powodzenia.

Proces ten nie dokonał się bez sprzeciwu ze strony uczelni, choć poza Konferencją Rektorów Akademickich Szkół Polskich (KRASP) nie istniały żadne organizacje branżowe dostatecznie silne, by móc zarządzać przekazem medialnym. Dodatkową trudność sprawiała akademii jej specyficzna struktura organizacyjna. Firmy komercyjne (włączając $\mathrm{w}$ to niepubliczne uniwersytety) wykorzystują do kontaktu z mediami wyspecjalizowanych aktorów, konstruujących spójny przekaz dotyczący ich pracodawcy. Uniwersytety publiczne są słabo zhierarchizowane, ich pracownicy uznają się raczej za członków wspólnoty niż podwładnych, a dodatkowo, z racji wykonywanego zawodu, posiadają status osób publicznych. Znaczna część publikowanych przez media krytycznych wypowiedzi na temat systemu NiSW była autorstwa akademików niższego szczebla, a także zajmujących pozycje na obrzeżu organizacji studentów i doktorantów. W tej sytuacji akademickim elitom trudno było minimalizować straty za pomocą strategii zarządzania wizerunkiem. Fakt partycypacji akademików w delegitymizacji systemu oznacza, że procesu tego nie należy traktować wyłącznie jako „zewnętrznej ingerencji” aktorów medialnych i Ministerstwa Nauki i Szkolnictwa Wyższego. Był to również, przynajmniej w pierwszych latach debaty, przejaw buntu często występujących anonimowo i prawie zawsze krytycznie nastawionych do zatrudniających ich instytucji akademickich proletariuszy.

Zgodnie z modelem kryzysów społecznych Jessopa spór o przyszły kształt akademii wiązał się z próbami dokonania systemowej rekonstrukcji przyczyn zdiagnozowanych problemów i możliwych ścieżek przyszłego rozwoju. W działalności tej brali udział nie tylko silnie zorganizowani aktorzy, tacy jak MNiSW czy KRASP, ale też przedstawiciele każdego szczebla akademickiej hierarchii, od rektorów poczynając, na studentach kończąc (jedynym wyjątkiem byli tu pracownicy admini- 
stracji, których z akademią łączą bardziej typowe stosunki pracodawca - zatrudniony).

Treść tych rekonstrukcji miała dość wyraźne powiązanie z materialnym interesem dokonujących ich stron. Zdając sobie sprawę, że od tego, komu zostanie przypisana wina za dotychczasowe „porażki”, może zależeć ich przyszła pozycja w systemie, aktorzy formułowali analizy mające uzasadniać ich roszczenia do utrzymania pozycji w systemie. Proces ten wyzwolił swoistą „cyrkulację winy”, w ramach której źródła systemowej patologii były, w spirali wzajemnych oskarżeń, przerzucane z aktora na aktora. Wina była też „wypychana” z systemu, gdy aktorzy uzasadniali swoje działania presją wywieraną na nich przez instytucje czy osoby stojące wyżej $\mathrm{w}$ hierarchii, a te z kolei przypisywały ją coraz bardziej ogólnym mechanizmom i tendencjom, takim jak urynkowienie, europeizacja czy globalizacja (Stankiewicz, 2014).

Choć dyskurs był tu narzędziem politycznego sporu, a konstruowanie go miało charakter strategiczny i było ściśle uzależnione od interesów poszczególnych aktorów, to intensywność wyzwolonych w trakcie debaty procesów wiedzotwórczych pozwoliła na pojawienie się dość precyzyjnego obrazu systemu, który wcześniej nie był sferze publicznej znany. Negatywną konsekwencją okazała się całkowita utrata przez szkoły wyższe kontroli nad dotyczącym ich przekazem i w konsekwencji - utrata społecznego zaufania. Poznawczy dysonans doświadczany przez aktorów debaty, tj. rozbieżność między odziedziczonym z przeszłości językiem a niemożliwą do zrozumienia $\mathrm{w}$ jego ramach rzeczywistością, doprowadził do rozsadzenia kulturowo zakorzenionego obrazu akademii. W przebiegu debaty każdy z aktorów należących do systemu - od oskarżanych o lenistwo i konformizm pracowników niższego szczebla, przez uznawanych „nie [za] przedmioty, lecz podmioty socjologicznego namysłu” studentów, po mających stanowić rdzeń „akademickiego feudalizmu" profesorów - został w ramach którejś z rekonstrukcji uznany za źródło wszystkich problemów szkół wyższych. Dyskursy te, rażąco odmienne od obrazów akademickiej rzeczywistości konstruowanych przed 2008 r., nadal stanowią bazę dla dokonywanych przez media i akademików analiz. Najtrwalszy wpływ wywarły na dyskusję o zasadności procesu umasowienia - przed $2008 \mathrm{r}$. było ono uznawane za proces koniecznej zmiany społecznej, zbliżającej polską rzeczywistość do „europejskiej średniej”. Obecnie waloryzuje się je negatywnie, za wzór do naśladowania uznając niemiecki system szkoleń zawodowych. W ten sposób nie tylko uniwersytety i ich pracownicy, ale i sama idea powszechnego wykształcenia na poziomie wyższym padła ofiarą kryzysu legitymizacji.

Wytwarzaniem dyskursu nie zajmowali się wyłącznie akademicy, studenci i publicyści. W procesie tym wzięło również udział państwo. Przez cały okres planowania reform było ono jedną z głównych stron sporu dotyczącego ich kształtu, a po ich wprowadzeniu głównym adresatem zarzutów co do sposobu funkcjonowania systemu. Dyskurs był więc dla niego, podobnie jak i dla pozostałych aktorów, narzędziem 
umożliwiającym prowadzenie walki o uzyskanie i zachowanie pozycji w systemie. Co więcej, sam powrót państwa, po długiej nieobecności, do aktywnej roli w polu NiSW był jednym z głównych czynników inicjujących procesy akumulacji wiedzy i w konsekwencji tworzących grunt dla kryzysu legitymizacji - po pierwsze dlatego, że wiązało się z nim upolitycznienie (i związane z tym prawie automatyczne przeniesienie do przestrzeni medialnej) konfliktu wokół pożądanej reakcji systemu na niż demograficzny; po drugie dlatego, że wpływ państwa jako potencjalnego arbitra czy zarządzającego całym polem organizacji hegemona oznaczał istotną korektę funkcjonujących od lat 90. i niesprzyjających powstawaniu przeznaczonej dla sfery publicznej wiedzy, leseferystycznych mechanizmów regulacji sektora.

Bliższa analiza interakcji pomiędzy państwem i rynkiem pozwala zdać sprawę z tych aspektów ewolucji pola NiSW, które najpierw przez długi okres tłumiły procesy tworzenia wiedzy, a później wyzwoliły je w gwałtowny i - z perspektywy akademii - niefortunny sposób.

\section{Państwo i rynek}

Kryzys legitymizacji nie pojawił się samoistnie. Towarzyszyły mu i warunkowały zmiany dokonujące się zarówno w otoczeniu szkół wyższych, jak i we wzajemnych stosunkach partycypujących w systemie aktorów społecznych. Okolicznością, która w największym stopniu wpłynęła na ewolucję sektora, był zbliżający się niż demograficzny. Wpłynął on na kalkulacje rządzące stosunkami pomiędzy szkołami publicznymi i niepublicznymi, a później wymusił powrót państwa do roli instytucji regulującej i zarządzającej sektorem.

W okresie systemowej ekspansji państwo pozostawało bierne - pozwalając na nieograniczony i nieregulowany rozrost masowej edukacji. Bierność ta nie generowała szerokiego sprzeciwu, ponieważ aktorzy tego opartego na ekonomicznej wolności i potężnym popycie systemu brali udział w przynoszącej zyski wszystkim uczestnikom grze o sumie dodatniej (Kwiek 2010). Szkołom wyższym ekspansja dawała możliwość rozwoju bez konkurowania z innymi instytucjami, studentom - tanią, niewymagająca i nieskoncentrowaną wyłącznie w centrach miejskich edukację masową, państwu - możliwość przypisania sobie sukcesu, za jaki uznawano „polski cud edukacyjny”, bez inwestowania nadmiernej ilości pieniędzy czy wysiłku i kapitału politycznego, niezbędnych, by system uregulować. Brak konfliktów - zarówno tych, które znajdowałyby wyraz w rynkowej konkurencji, jak i tych, które mogłyby ulec upolitycznieniu, prowadząc do pojawienia się dyskursu publicznego, w połączeniu z faktem, że każda ze stron czerpała z systemu korzyści - oznaczał, że o szkołach wyższych nie mówiono i nie wiedziano zbyt wiele.

Rozpowszechnienie wiedzy na temat natury zmian mogłoby umożliwić ewolucyjne przystosowanie świadomości społecznej do nowej rzeczywistości i zapobiec 
lub przynajmniej złagodzić szok z końca pierwszej dekady XXI wieku. Przyjęte rozwiązania systemowe oznaczały jednak, że żaden z aktorów nie posiadał motywacji do tworzenia takiej wiedzy. Kluczową rolę odgrywała leseferystyczna polityka państwa. Ponieważ nie planowało ono kształtu stosunków społecznych, określając tylko ogólne granice sfery, w której miały się one zgodnie z właściwą sobie logiką rozgrywać, jego potrzeby w zakresie wytwarzania i konsumpcji wiedzy były bardzo ograniczone.

Z perspektywy leseferystycznej filozofii politycznej taka dyskursywna bierność może być odczytywana nie jako zaniedbanie, ale przejaw racjonalnego ograniczenia ambicji władzy centralnej. Słabość tej ostatniej w porównaniu z rozwiązaniami opartymi na wolnym rynku ma, według przedstawicieli tej doktryny, brać się z jej niezdolności do uzyskania wyczerpującej wiedzy na temat społecznej działalności, którą mogłaby ona chcieć zarządzać (Hayek 1945). Wiedza generowana przez jednostki posiada ograniczony zakres (obejmując wyłącznie dane indywiduum i jego otoczenie społeczne), ale znacznie większą niż w wypadku dyskursu wytwarzanego centralnie precyzję. Ponieważ jej wykorzystanie jest motywowane interesem własnym, nie będzie ona nigdy ignorowana. Ponieważ działanie rodzi się z niej u jej źródła, pozwala ona natychmiast reagować na zmieniającą się sytuację.

$\mathrm{W}$ tym ujęciu istnienie wiedzy generowanej centralnie i w konsekwencji tego, co nazywamy tu dyskursem (tzn. wiedzy produkowanej w ramach i na potrzeby sfery publicznej), nie jest do funkcjonowania społeczeństwa niezbędne. Działalność indywidualna jest całkowicie wystarczająca, by poradzić sobie z głównym ekonomicznym wyzwaniem, za które uważa się „szybką adaptację do zmian dokonujących się w danym czasie i miejscu" (Hayek 1945: 524).

System SWiN, który funkcjonował w Polsce w latach 1989-2008, dość dokładnie odpowiadał zarysowanym powyżej założeniom. Można podejrzewać, że nawet gdyby istniały zainteresowane tym agendy, w sytuacji gwałtownej zmiany systemowej, a także wobec bezprecedensowości kierunku ewolucji systemu - zarówno jeśli chodzi o ich szybkość, jak i kontekst społeczny, w którym zachodziły - jakiekolwiek prognozowanie miałoby znikomą wartość. Zrzeczenie się tej ambicji i zdanie na przemyślność jednostek była najprawdopodobniej jedynym rozwiązaniem, które nie wiązało się z ryzykiem zamrożenia systemu w znanym kształcie i sparaliżowaniem jego zdolności odpowiadania na potrzeby społeczne. Możliwość, czy wręcz konieczność, wytworzenia wiedzy niezbędnej do procesu planowania pojawiła się dużo później - gdy okres gwaltownych zmian się zakończyl, a system przyjął dobrze zdefiniowaną formę, której rozwój (lub upadek) można było prognozować.

Proces stabilizacji systemu rozpoczął się w latach 2003-2010, gdy ekspansja ustąpiła stagnacji (średni wzrost liczby studentów spadł z 15\% do 0,5\% rocznie), a gra o sumie dodatniej - grze o sumie zerowej. W ramach tej ostatniej każdy zysk (w poziomie rekrutacji i tym samym finansowania) musiał być okupiony czyjąś stratą. Sytuacja ta nie doprowadziła do nasilenia rynkowej konkurencji, ponieważ 
nie sprzyjała temu struktura polskiego rynku edukacyjnego - brak ogólnokrajowego rynku usług edukacyjnych (związany z nieistnieniem sektora elitarnego; Karabel 2005), jednocześnie hierarchiczny i symbiotyczny charakter związków pomiędzy sektorem publicznym i niepublicznym. Szkoły niepubliczne nie posiadały ani społecznego prestiżu, ani dostępu do finansowania na poziomie pozwalającym na mierzenie swoich sił ze szkołami publicznymi. Dodatkowo obie kategorie szkół opierały się na tej samej kadrze - posiadającej uprawnienia do nauczania dzięki swojej pracy w sektorze publicznym i nie bez reszty spauperyzowanej dzięki sektorowi niepublicznemu. Ta ostatnia kwestia - pracy wykładowców na wielu etetach - była głównym tematem medialnej dyskusji z lat 2000-2003. Starania rektorów publicznych uniwersytetów (mogące służyć ochronie wizerunku ich szkół lub uderzeniu w niepubliczną konkurencję), dążących do jej ukrócenia, stanowiły jeden z pierwszych sygnałów tego, że niemogący znaleźć wyrazu na poziomie rywalizacji rynkowej, spór o zasoby może przenieść się do przestrzeni politycznej (nawet jeśli w tym wypadku chodziło jedynie o politykę uczelni) i w konsekwencji, niejako automatycznie - w przestrzeń mediów masowych.

Efektem braku konkurencji było zamrożenie sektora - w okresie stagnacji szkoły publiczne i niepubliczne dzieliły między siebie studentów w niezmieniających się proporcjach. Zagrożenie związane z tą sytuacją wynikało z tego, że w perspektywie kilku lat stagnacja miała ustąpić związanej z niżem demograficznym kontrakcji (Antonowicz, Godlewski 2011). Brak rynkowej redystrybucji zasobów ze słabszych ośrodków do silniejszych, połączony z konsekwencjami leseferyzmu - dającego jednostkom i organizacjom możliwość reagowania na zmieniającą się sytuację, ale niezakładającego ani możliwości, ani konieczności istnienia mechanizmów pozwalających na przeprowadzanie zmian ogólnosystemowych - oznaczały, że sektor nie był zdolny ani do przygotowania się, ani przystosowania do nadchodzącego niżu demograficznego. Jedynym aktorem posiadającym środki mogące zapewnić mu ten rodzaj sterowności było państwo.

Okres kontrakcji stanowi grę o sumie ujemnej - w jej ramach nie jest możliwe utrzymanie swojego stanu posiadania bez pozyskiwania zasobów kosztem innych. Utrzymanie w takiej sytuacji status quo na poziomie pojedynczej organizacji wymaga zaangażowania się w konflikt. Uniknięcie konfliktu jest możliwe, jeśli strony potrafią zawrzeć kompromis, dzielący straty w sposób, który wszyscy zainteresowani uznają za sprawiedliwy (Burgess i Burgess 1997). Główne strony sporu były zainteresowane wykorzystaniem mechanizmów państwa do dokonania podziału kosztów, choć przewidywane przez nie rozwiązania trudno uznać za sprawiedliwe. W latach poprzedzających rozpoczęcie kryzysu rektorzy szkół publicznych wielokrotnie wyrażali swoje poparcie dla zmian wprowadzających powszechne czesne, co byłoby równoznaczne z przerzuceniem kosztów kontrakcji na najsłabszego i najbardziej podzielonego z interesariuszy systemu edukacji wyższej - studentów. Czesne mogłoby zapewnić szkołom publicznym dopływ dodatkowych środków, nie 
zmieniając w znaczący sposób równowagi wpływów w systemie. Szkoły publiczne utraciłyby jedno ze źródeł przewagi nad niepublicznymi - „darmowe” studia - ale zachowałyby wyższy prestiż i płynącą z dywersyfikacji źródeł dochodu niezależność od wpływów państwa. Rektorzy i założyciele szkół niepublicznych występowali w tym sporze z podobnych pozycji, walcząc o przyznanie im (przewidzianych w ustawie z 2005 r.) dopłat do działalności dydaktycznej. Gdy państwo zaangażowało się w regulację systemu, a jednocześnie żądania największych aktorów okazały się niemożliwe do realizacji (wprowadzenie powszechnego czesnego z powodów konstytucyjnych, a powszechnych dopłat do działalności dydaktycznej - budżetowych) spór o metodę przygotowania systemu na konsekwencje niżu przeniósł się do przestrzeni medialnej, co uczyniło kryzys legitymizacji akademii trudnym do uniknięcia.

Ostateczny kształt reformy nie naruszył interesów szkół publicznych i studentów. Wzrost nakładów państwa (wykres 2) miał zapełnić lukę powstałą w wyniku zmniejszenia przychodów z czesnego. Szkoły niepubliczne nie uzyskały środków publicznych, co było równoznaczne z ich stopniowym upadkiem.

Wykres 2. Publiczne i prywatne nakłady na edukację wyższą

(w mld zł z 2015 r., GUS 2004-2014)

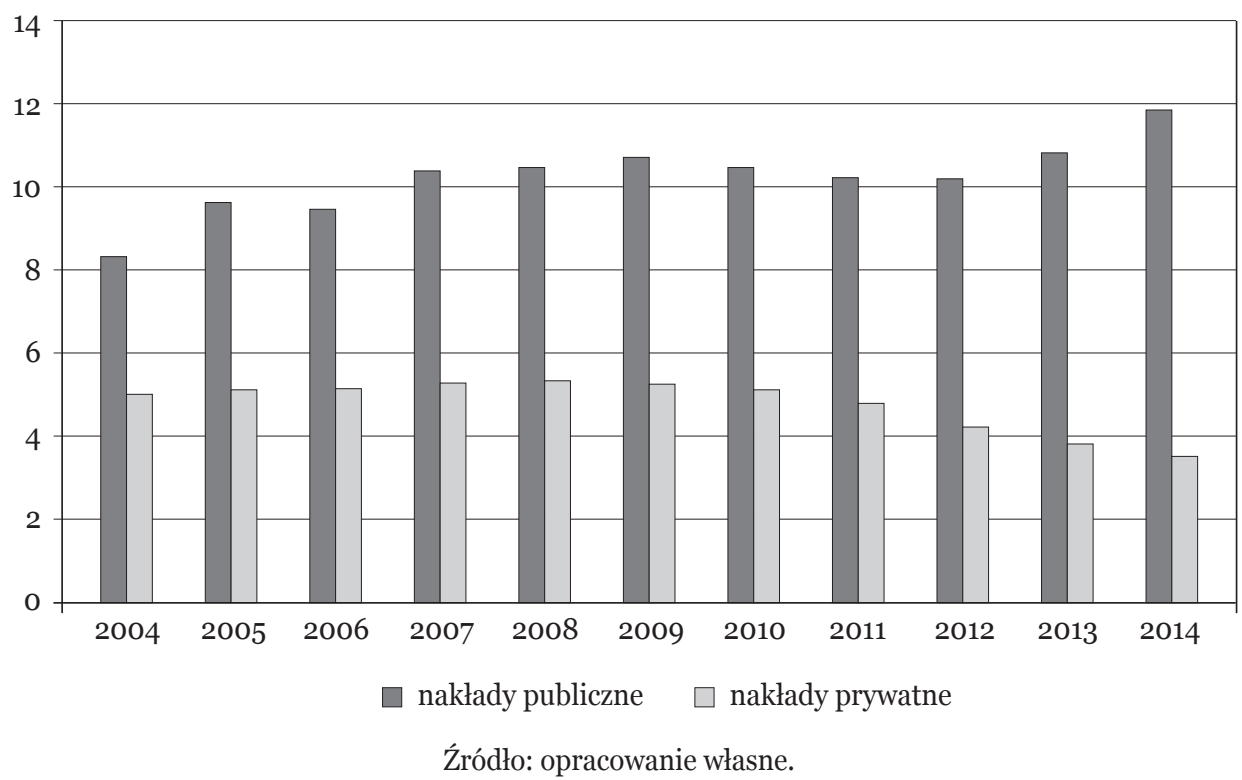

Te generalnie sprzyjające sektorowi publicznemu rozwiązania $\mathrm{w}$ gruntowny sposób przekształcają stosunki między szkołami a ministerstwem. Spadek dywersyfikacji przychodów, konieczność zdania się całkowicie na finansowanie publiczne 
oznacza, że uniwersytety są o wiele bardziej poddane państwowej kontroli. Sytuacja ta nie pozostaje bez wpływu na sferę dyskursu i społecznej legitymizacji.

Państwo występujące w roli planisty akumuluje wiedzę na temat szkół wyższych (i udostępnia ją publicznie) w stopniu nieporównywalnym z państwem, którego jedyną ambicją jest stworzenie pola gry dla autonomicznych jednostek i organizacji. Akumulacja wiedzy - wyrażająca się w ocenie efektów kształcenia (w tym dochodu i stopnia bezrobocia absolwentów) i osiągnięć naukowych pracowników akademickich - wynika z dążenia do kwantyfikacji i jasnego zdefiniowania produktów szkół wyższych, a tym samym trwałego przesunięcia ich ze sfery organizacji legitymizowanych kognitywnie-kulturowo do sfery racjonalnego rachunku i zarządzania. Te konsekwencje są naturalne, zarówno jeśli weźmie się pod uwagę zmianę w równowadze wpływów pomiędzy szkołami i ministerstwem, jak i stanowiące bazę polskich reform globalne wzorce zmian w systemach NiSW (Antonowicz 2015a). Oznacza to, że proces rozpoczęty przez publiczny spór wokół akademii nie zakończy się wraz z domknięciem reform - mechanizmy generowania wiedzy na temat systemu i jego produktów zostały wpisane w samą konstrukcję stosunków pomiędzy aktorami, trwale przekształcając naturę „społecznego kontraktu” między uniwersytetami a ich społecznym otoczeniem.

\section{Podsumowanie}

Uniwersytety, podobnie jak inne instytucje świata zachodniego, w ciągu całego wieku XX doświadczały powolnej ewolucji od bycia organizacjami legitymizowanymi kognitywnie-kulturowo, przez (mającą wyraz w Weberowskiej racjonalnej biurokracji i progresywnym zwrocie w administracji publicznej; Lane 2000) działalność opartą na regułach, po (stanowiące podstawę nurtu New Public Management; O’Flynn 2007) tryby funkcjonowania mające emulować działanie organizacji rynkowych. Ze względu na swój ekspercki charakter (i znaczny kredyt społecznego zaufania) uniwersytety dobrze radzily sobie w okresie progresywnej rewolucji $\mathrm{w}$ administracji publicznej. Znacznie większy sprzeciw budzą najnowsze zmiany - transformacja z instytucji w racjonalną organizację, której procesy wytwórcze nie są celem samym w sobie, ale środkiem do realizacji zamiarów jednostek, państwa i gospodarki (Olsen 2005; Kwiek 2016b).

Z tej ostatniej zmiany, której prefiguracje były widoczne w procesie instrumentalizacji badań naukowych w okresie zimnej wojny, czy jeszcze wcześniej w ścisłym powiązaniu między reformami edukacyjnymi a militarnymi porażkami XIX-wiecznych państw (Stankiewicz 2014), a dziś mającej wyraz w rosnącym znaczeniu edukacji wyższej jako usługi skierowanej do międzynarodowego klienta (Marginson 2006) oraz teoriach łączących rozwój naukowy ze wzrostem gospodarczym (Romer 1994), wynikają próby precyzyjnego zdefiniowania tego, co w ramach organizacji 
zinstytucjonalizowanych zawsze pozostawało niejasne i ambiwalentne - natury wytwarzanych przez nie produktów i usług. Ta jasna definicja nauki i nauczania mająca umożliwić jej klientom racjonalną analizę zysków i strat z ich nabywania, a także racjonalne zarządzanie personelem akademickim, wymaga „odczarowania” tej instytucji (Antonowicz 2015a) i dokonania racjonalizacji antytetycznej wobec kognitywno-kulturowej bazy jej dotychczasowej legitymizacji.

Niezależnie od okoliczności proces ten byłby współcześnie trudny do uniknięcia ze względu na obiektywny sukces uniwersytetów, które z szacownych i niewielkich instytucji stały się gałęzią przemysłu, od której uzależnione są zarówno współczesne państwa, korzystające z wytwarzanej w akademii wiedzy i efektów sieciowych, czyniących z największych uniwersytetów centra klastrów przemysłowych, jak i klasa średnia, dla której edukacja stała się towarem pierwszej potrzeby, zapewniając jej dzieciom pozycjonalną przewagę w walce o miejsce w cechującej się coraz większymi nierównościami hierarchii społecznej. Do „odczarowania” polskiego uniwersytetu doszło w momencie, w którym zarówno państwo, jak i klasa średnia (której odbiciem stanu świadomości jest niewątpliwie Gazeta Wyborcza) zaczęły zdawać sobie sprawę z tego, w jakim stopniu stały się lub muszą się stać w niedalekiej przyszłości zależne od działalności prowadzonej na sposób mający więcej wspólnego ze średniowieczną gildią niż stanowiącą współczesny wzorzec efektywności firmą komercyjną.

Otwartą pozostaje kwestia, czy funkcjonowanie uniwersytetu może być poddane racjonalizacji. Urynkowienie misji nauczania, jak pokazuje przykład wielkich komercyjnych uniwersytetów USA (a także będących formalnie instytucjami non-profit polskich szkół niepublicznych), wiąże się ze znaczącym poszerzeniem dostępu do wykształcenia wyższego, ale też z ryzykiem zamiany akademii w niezajmujące się tworzeniem wiedzy, sprzedające dyplomy lub starające się generować zysk bez zważania na dobro swoich studentów „pseudouniwersytety” (Altbach 2015; Morse 2015). Czysto komercyjna logika nie sprawdza się również w zakresie finansowania prowadzonych przez uniwersytety badań podstawowych (Nelson 1959; Geiger 2004). Choć wiedza uzyskana dzięki tym ostatnim stanowi fundament cywilizacji technicznej, to jej zdobywanie, jako mniej lub bardziej przypadkowa eksploracja nieznanych wcześniej ludzkości dziedzin, wiąże się z niepewnością wykraczającą poza policzalne, i tym samym mogące stanowić podstawę kalkulacji zysków i strat ryzyko. Instytucje akademickie są siedliskiem wielu innych procesów o nieintuicyjnej naturze ${ }^{5}$, wymykającej się zarówno racjonalności normy i organizacji, jak i racjonalności rynku. Pozwalająca na działanie przy minimum nadzoru legitymizacja oparta na autorytecie, przy całym potencjale nadużyć, jaki się z nią wiąże, ma przynajmniej tę jedną przewagę nad nadzorem opartym na normach czy rynku,

${ }^{5}$ Ich przykładami mogą być pozycjonalna natura wykształcenia (Hollis 1982) czy fakt, że wiedza ma cechy dobra publicznego (Szadkowski 2015). 
że umożliwia społeczeństwu ukrycie przed samym sobą irracjonalnej natury procesów, które są dla niego konstytutywne. Z kolei odczarowanie uniwersytetu i powiązane z nim procesy reformy mogą przyjąć postać, tak częstej we współczesnych państwach (Scott 1998), ingerencji jednocześnie ściśle racjonalnej i - właśnie przez swą nieszanującą złożoności organizacyjnej „ekologii” racjonalność - kontrproduktywnej.

\section{Literatura}

Altbach, P. (2015). The rise of the pseudouniversities. http://ejournals.bc.edu/ojs/index. php/ihe/article/viewFile/6947/6164 [1.04.2016].

Antonowicz, D. (2015a). Między sita globalnych procesów a lokalnq tradycją: polskie szkolnictwo wyższe $w$ dobie przemian. Toruń: Wyd. Naukowe UMK.

Antonowicz, D. (2015b). Perspektywa neoinstytucjonalna w badaniach nad przemianami szkolnictwa wyższego w Polsce. Nauka i Szkolnictwo Wyższe. 1(45): 75-94.

Antonowicz, D., Godlewski, B. (2011). Demograficzne tsunami. Raport Instytutu Sokratesa na temat wphywu zmian demograficznych na szkolnictwo wyższe do 2020 roku. Warszawa: Instytut Rozwoju Kapitału Intelektualnego im. Sokratesa.

Ashforth, B.E., Gibbs, B.W. (1990). The Double-edge of Organizational Legitimation. Organization Science. 1(2): 177-194.

Burgess, H., Burgess, G.M. (1997). Encyclopedia of Conflict Resolution. Santa Barbara: ABC-CLIO.

Deephouse, D.L. (1996). Does isomorphism legitimate? Academy of Management Journal. 39(4): 1024-1039.

DiMaggio, P. (1997). Culture and Cognition. Annual Review of Sociology. 23: 263-287.

Geiger, R. (2004). Knowledge and Money: Research Universities and the Paradox of the Marketplace. Stanford: Stanford University Press.

Goode, E., Ben-Yehuda, N. (1994). Moral Panics: The Social Construction of Deviance. Oxford: Blackwell.

GUS (2005). Szkoły wyższe i ich finanse $w 2004$ roku. Warszawa.

GUS (2006). Szkoły wyższe i ich finanse $w 2005$ roku. Warszawa.

GUS (2007). Szkoly wyższe i ich finanse w 2006 roku. Warszawa.

GUS (2008). Szkoly wyższe i ich finanse w 2007 roku. Warszawa.

GUS (2009). Szkoły wyższe i ich finanse $w 2008$ roku. Warszawa.

GUS (2010). Szkoły wyższe i ich finanse w 2009 roku. Warszawa.

GUS (2011). Szkoły wyższe i ich finanse $w 2010$ roku. Warszawa.

GUS (2012). Szkoły wyższe i ich finanse $w 2011$ roku. Warszawa.

GUS (2013). Szkoly wyższe i ich finanse w 2012 roku. Warszawa.

GUS (2014). Szkoły wyższe i ich finanse $w 2013$ roku. Warszawa.

GUS (2015). Szkoły wyższe i ich finanse w 2014 roku. Warszawa.

Hayek, F.A. (1945). The Use of Knowledge in Society. The American Economic Review: 35(4): 519-530. 
Hollis, M. (1982). Education as a positional good. Journal of Philosophy of Education, 16(2): 235-244.

Jessop, B. (2002). The Future of the Capitalist State. Cambridge: Polity.

Karabel, J. (2005). The Chosen: The Hidden History of Admission and Exclusion at Harvard, Yale, and Princeton. Boston: Houghton Mifflin.

Kwiek, M. (2009). The two decades of privatization in polish higher education. Cost-sharing, equity, and access. W: J. Knight (red.), Financing Access and Equity in Higher Education (149-167). Papendrecht: Sense Publishers.

Kwiek, M. (2010). Transformacje uniwersytetu: zmiany instytucjonalne i ewolucje polityki edukacyjnej w Europie. Poznań: Wyd. Naukowe UAM.

Kwiek, M. (2013). From System Expansion to System contraction: Access to Higher Education in Poland. Comparative Education Review. 57(3): 553-576.

Kwiek, M. (2016a). From Privatization (of the Expansion Era) to De-privatization (of the Contraction Era): A National Counter-Trend in a Global Context. W: Higher Education. Stratification, and Workforce Development (311-329). miasto: Springer.

Kwiek, M. (2016b). Constructing Universities as Organizations: University Reforms in Poland in the Light of Institutional Theory. https://repozytorium.amu.edu.pl/handle/10 593/14018 [19.03.2016].

Lane, J.-E. (2000). New Public Management. New York: Routledge.

Marginson, S. (2006). Dynamics of National and Global Competition in Higher Education. Higher Education. 52(1): 1-39.

Meyer, J.W., Rowan, B. (1977). Institutionalized Organizations: Formal Structure as Myth and Ceremony. American Journal of Sociology. 83(2): 340-363.

Morse, S. (2015). For-Profit Schools: A History of Abuse and the Need for Reform. Brigham Young University Education and Law Journal. 2: 585-595.

Nelson, R.R. (1959). Simple Economics of Basic Scientific Research, The. The Journal of Political Economy. 67(3): 297-306.

O’Flynn, J. (2007). From New Public Management to Public Value: Paradigmatic Change and Managerial Implications. Australian Journal of Public Administration. 66(3): 353366.

Olsen, J.P. (2005). The Institutional Dynamics of The (European) University. https:// www.researchgate.net/profile/Johan_Olsen3/publication/5014564_The_Institutional_Dynamics_of_the_(European)_University_Working_Paper_15/links/55d2foc 808aeob8f3ef8f91e.pdf [19.03.2016]

Romer, P.M. (1994). The Origins of Endogenous Growth. The Journal of Economic Perspectives. 8(1): 3-22.

Scott, J.C. (1998). Seeing like a state: How certain schemes to improve the human condition have failed. New Haven: Yale University Press.

Scott, W. (2008). Institutions and Organizations Ideas and Interests. Los Angeles: Sage.

Scott, W.R., Meyer, J.W. (1991). The Organization of Societal Sectors. The New Institutionalism in Organizational Analysis (108-140). Chicago: Chicago University Press.

Selznick, P. (1957). Leadership in Administration: A Sociological Interpretation. Evanston: Row Peterson. 
Stankiewicz, Ł. (2014). Wizje uniwersytetu w Polskiej debacie publicznej 2007-2009 (niepublikowana praca doktorska).

Stankiewicz, Ł. (2015). Pułapka umasowienia - o sprawczości jednostek w umasowionym systemie szkolnictwa wyższego. Nauka i Szkolnictwo Wyższe. 1(45): 191-213.

Stankiewicz, Ł. (2016). Krytyka umasowienia szkolnictwa wyższego w Polsce i Stanach Zjednoczonych - analiza dyskursu mediów masowych (w druku).

Szadkowski, K. (2015). Uniwersytet jako dobro wspólne: podstawy krytycznych badań nad szkolnictwem wyższym, Warszawa: Wyd. Naukowe PWN.

Suchman, M.C. (1995). Managing Legitimacy: Strategic and Institutional Approaches. The Academy of Management Review. 20(3): 571-610.

Wolszczak-Derlacz, J. (2015). Analiza efektywności działalności uczelni europejskich i amerykańskich - podejście nieparametryczne. Ekonomia. 40: 109-130.

Wolszczak-Derlacz, J., Parteka, A. (2010). Produktywność naukowa wyższych szkół publicznych w Polsce. Bibliometryczna analiza porównawcza. Sprawne Państwo. Warszawa: Ernst\&Young.

\title{
The Role of Social Knowledge and Legitimation in the Transformations of the Polish University
}

\begin{abstract}
Over the last decade the polish higher education and science sector experienced a series of policy changes that radically altered its relation with the state. In the course of a public debate concerning the new policies, the workers, practices and institutions of the university were criticized, which strongly influenced the image of the academic world in the public sphere. The aim of this paper is to describe mechanisms of change in public knowledge and legitimation of higher education and science sector in post-1989 Poland. The description is informed by a qualitative analysis of press content - Gazeta Wyborcza from 1989 to 2014. The effects of public debate that has taken place between 2008 and 2014 are described as a legitimation crisis of the polish university. This crisis forced university's transition from a traditional, authority based mode of legitimation to a rational and pragmatic legitimation based on a precise, quantified definition of products offered by the schools, and highly reliant on the mechanisms of the state.
\end{abstract}

KEYWORDS: higher education, legitimation, discourse analysis, legitimation crisis

CYTOWANIE: Stankiewicz, Ł. (2015). Społeczna wiedza i legitymizacja a przemiany polskiego uniwersytetu. Nauka i Szkolnictwo Wyższe. 2(46): 139-159. DOI:10.14746/nsw.2015.2.5. 